\begin{tabular}{|c|c|c|c|c|}
\hline Share: Social Work Jurnal & VOLUME: 10 & NOMOR: 1 & HALAMAN: $29-39$ & $\begin{array}{c}\text { ISSN: 2339-0042 (p) } \\
\text { ISSN: 2528-1577 (e) } \\
\text { DOI: 10.24198/share.v10i1.25992 }\end{array}$ \\
\hline
\end{tabular}

\title{
TINGKAT STRESS PENYALAHGUNA NAPZA SAAT MENJALANI REHABILITASI DI INABAH XV PONDOK PESANTREN SURYALAYA
}

\author{
Ahmad Saalik Hudan Alfariz ${ }^{1}$, Budi Muhammad Taftazani², \\ ${ }^{1}$ Universitas Padjajaran \\ saalikhudan@gmail.com \\ 2, Pusat Studi CSR, Kewirausahaan Sosial dan Pemberdayaan Masyarakat, Universitas Padjadjaran \\ taftazani@unpad.ac.id
}

\begin{abstract}
ABSTRAK
Penelitian ini dilakukan untuk memperoleh gambaran mengenai tingkat stress yang dialami santri binaan yang sedang menjalani proses rehabilitasi penyalahgunaan Napza di Inabah Pondok Pesantren Suryalaya Tasikmalaya. Tujuan penelitian untuk mengidentifikasi karakteristik penyalahguna NAPZA, mengukur tingkat stress penyalahguna NAPZA pada aspek fisiologis, emosional, dan perilaku. Metode yang digunakan dalam penelitian adalah kuantitatif dengan metode deskriptif. Teknik pengambilan sampel yang digunakan yaitu sensus dengan jumlah 37 orang responden. Teknik pengumpulan data menggunakan kuesioner baku yang dimodifikasi untuk mengukur tingkat stress. Katagori tingkat stress yaitu, ringan, sedang dan berat. Validitas alat ukur menggunakan validitas muka dan teknik analisis data dengan statistik deskriptif dan tabulasi data. Hasil penelitian menunjukkan bahwa korban penyalahguna NAPZA mengalami stress pada tingkat sedang saat menjalani rehabilitasi. Hal ini dilihat berdasarkan skor pada ketiga aspek stress yaitu fisiologis, emosional dan perilaku. Dari ketiga aspek tersebut stress pada aspek emosional menunjukkan skor tertinggi.
\end{abstract}

Kata kunci : Stress, Penyalahaguna NAPZA, Rehabilitasi

\begin{abstract}
This research was conducted to obtain an overview of the level of stress experienced by the assisted students who are undergoing the rehabilitation process of drug abuse at Inabah Pondok Pesantren Suryalaya Tasikmalaya. The aim of this research is to identify the characteristics of drug abusers, to measure the stress level of drug abusers in physiological, emotional, and behavioral aspects. The method used in this research is quantitative with descriptive methods. The sampling technique used was a census with 37 respondents. The data collection technique used a modified standard questionnaire to measure stress levels. Stress level categories are mild, moderate and severe. The validity of the measuring instrument used advance validity and data analysis techniques with descriptive statistics and data tabulation. The results showed that drug abusers experienced moderate stress while undergoing rehabilitation. This can be seen based on the scores on the three aspects of stress, namely physiological, emotional and behavioral. Of the three aspects, stress on the emotional aspect shows the highest score.
\end{abstract}

Keywords: Stress, Drug Abuse, Rehabilitation

\section{PENDAHULUAN}

Masalah penyalahguna Narkotika, Psikotropika dan Zat Adiktif lainnya (NAPZA) merupakan masalah sosial yang merusak masyarakat khususnya generasi muda. Dengan demikian masalah sosial yang satu ini dapat dikategorikan sebagai masalah bangsa yang perlu segera diatasi. 
NAPZA adalah bahan/zat yang jika dimasukan dalam tubuh manusia, baik secara oral/diminum, dihirup, maupun disuntikan, dapat mengubah pikiran, suasana hati atau perasaan, dan perilaku seseorang. NAPZA dapat menimbulkan ketergantungan (adiksi) fisik dan psikologis. Narkotika merupakan zat atau obat yang dapat berasal dari tanaman atau bukan tanaman, baik sintetis maupun semi sintetis yang aspabila dikonsumsi dapat menyebabkan penurunan atau perubahan kesadaran, hilangnya rasa nyeri dan dapat menimbulkan ketergantungan. NAPZA merupakan jenis obat/zat yang diperlukan di dalam dunia pengobatan, akan tetapi apabila dipergunakan tanpa batasan dan pengawasan yang seksama dapat menimbulkan ketergantungan serta dapat membahayakan kesehatan bahkan jiwa pemakainnya.

Data BNN pada tahun 2009 adalah 1,99 persen penduduk Indonesia berumur 10-59 tahun atau sekitar 3,6 juta orang terjerumus dalam penyalahgunaan NAPZA. Pada tahun 2010 prevalansi penggunaan NAPZA menjadi 2,21 persen atau sekitar 4,02 juta orang, dan pada tahun 2011 prevalensi pengunnan NAPZA meningkat menjadi 2,8 persen atau sekitar 5 juta orang (Parasian Simanungkalit, 2011). Kemudian pada tahun 2015, Kepala Badan Narkotika Nasional (BNN) mengatakan jumlah penggunaan NAPZA di tanah air mencapai 5,9 juta orang. Keadaan ini tentu sangat memprihatinkan mengingat remaja sebagai generasi penerus bangsa justru sebagai kelompok terbesasr penyalahguna NAPZA. Masalah penyalahgunaan NAPZA merupakan masalah sosial yang memiliki pengaruh negatif yang sangat kompleks, dikatakan kompleks karena pengaruh negatif tersebut mempunyai implikasi majemuk baik itu menyangkut aspek bilogis, psikologis, dan sosial bagi penggunannya dan termasuk juga mempunyai andil dalam membuat keresahan masyarakat serta menghilangkan generasi penerus bangsa. Dengan demikian penyalahguaan NAPZA sudah tidak lagi menjadi masalah hukum, tetapi juga menjadi masalah masyarakat yang perlu diatasi.
Pemerintah gencar melakukan
program pemulihan bagi korban penyalahguna NAPZA yaitu menjalankan program rehabilitasi bagi korban ketergantungan penyalahguna NAPZA. Program rehabilitasi dimaksudkan untuk memulihkan kondisi biopsikososial korban penyalahguna NAPZA agar mampu memperoleh keberfungsian sosialnya dan dapat kembali menjalani kehidupan di masyarakat. Keberfungsian sosial merupakan suatu kondisi dimana seseorang mampu berelasi sosial, dapat memenuhi kebutuhan, mampu melaksanakan peran sosial secara mandiri dan normatif.

Selain dilakukan oleh pemerintah, masyarakat juga terlibat dalam usaha pemulihan korban penyalahgunaan NAPZA dengan mendirikan lembaga rehabilitasi. Salah satu lembaga yang didirikan masyarakat untuk melakukan rehabilitasi penyalahguna Napza adalah Inabah XV Pondok Pesantren Suryalaya. Inabah XV didirikan oleh $\mathrm{H}$. Kurniadi Pradja atas mandat langsung dari pemimpin Suryalaya yaitu KH. Ahmad Shohibulwafa Tajul Arifin yang akrab dipanggil dengan sebutan Abah Anom. Pondok Pesantren Suryalaya menjalankan satu tradisi Tasawuf yaitu Thariqah Qadiriyah Naqsabandiyah (TQN).

Inabah adalah istilah yang berasal dari Bahasa Arab anaba-yunibu (mengembalikan) sehingga Inabah berarti pengembalian atau pemulihan, yaitu proses kembalinya seseorang dari jalan yang menjauhi Allah ke jalan yang mendekat ke Allah. Abah Anom menggunakan nama Inabah menjadi nama metode bagi program rehabilitasi pecandu narkotika, remaja-remaja nakal, dan orangorang yang mengalami gangguan kejiwaan. Sedangkan pondok yang dijadikan tempat penerapan metode untuk rehabilitasi tersebut adalah pondok inabah XV. Konsep perawatan korban penyalahgunaan obat serta kenakalan remaja adalah mengembalikan orang dari perilaku yang selalu menentang kehendak Allah atau maksiat, kepada perilaku yang sesuai dengan kehendak Allah. Pada dasarnya metode yang diterapkan Inabah dalam proses 
rehabilitasi penyalaguna NAPZA adalah berbasis pendekatan spiritual TQN.

Metode spiritual yang diterapkan Inabah XV dilakukan melalui aktivitas ritual yaitu mandi, dzikir dan solat serta kegiatan ibadah lainnya seperti puasa dan manakiban yaitu kegiatan pengajian yang diadakan oleh pihak pesantren. Kegiatan-kegiatan ini wajib diikuti anak binaan dan akan mendapatkan hukuman apabila mereka tidak mengikuti kegiatan yang telah dijadwalkan. Anak binaan yang direhabilitasi di Inabah XV Pondok Pesantren Suryalaya harus mematuhi aturan-aturan yang ditetapkan oleh pihak lembaga. Mereka wajib tinggal dan menetap di asrama Pondok, harus mengikuti setiap kegiatan, mengikuti serangkaian tes kesehatan, dibatasinya akses komunikasi dengan mereka yang berada di luar pondok, tidak diperkenankan untuk keluar pondok dalam waktu yang ditentukan dan lain sebagainnya. Padatnya aktivitas serta aturan dan tata tertib yang ketat ditenggarai sebagai penyebab munculnya keadaan stress pada anak binaan.

Kontrasnya pola hidup yang dialami anak/santri binaan antara sebelum masuk pondok dengan saat masuk pondok dengan segala keketatan aturannya membuat anak binaan dihadapkan pada situasi yang sulit. Keadaan tertekan santri binaan penyalahguna NAPZA di Pondok Inabah XV Pesantren Suryalaya terjadi dan terlihat pada saat pemberian pelayanan. Diantara perilaku yang berhasil diamati yaitu tidak memperhatikan saat kegiatan rehabilitasi berlangsung, membuat keributan, tidak mengikuti kegiatan atau membolos, melawan pengurus Pondok Inabah XV, hingga kabur dari panti. Tahun 2010, berita di kompas.com melaporkan bahwa terdapat santri binaan yang hilang setelah melarikan diri dari pondok Inabah 17, dan ditemukan dalam keadaan tewas di bendungan sungai Citanduy, Kota Banjar, Jawa Barat, Jumat 5 maret 2010. Diantara mereka adalah Muhammad Nanda (14), Santri Binaan asal Yogyakarta, yang ikut melarikan diri bersama 14 rekannya pada hari Sabtu 27 Februari 2010. Pelarian itu dilakukan setelah mereka menjebol atap kamar dan kemudian menyeberangi sungai yang berada dibelakang Pondok. Pimpinan Pondok yang berlokasi di Kecamatan Cihaurbeuti, Kabupaten Ciamis, Jawa Barat, H Yaya Mulyadi, menduga, para Santri Binaan itu melarikan diri karena merasa tidak nyaman dan bebas seperti ketika masih tinggal bersama keluarga. Selain itu menurut Humas inabah XV Pesantren Suryalaya, Ridwan Maulana Yusuf menuturkan " memang betul telah terjadi stress yang dialami santri binaan di Inabah XV ini, hanya tingkatannya berbeda, ada juga yang sudah sampai tingkat halusinasi dan depresi. Santri di Inabah XV ini beragam dalam kasusnya atau awal mulainya masuk ke Inabah XV untuk mengikuti rehabilitasi. Hanya saja kebanyakan mengikuti rehabilitasi dilatar belakangi keterpaksaan." Ungkapan bagian Humas Inabah ini diperoleh saat penulis melakukan penjajagan pada tanggal 25 Desember 2017. Informasi mengenai gejala stress juga penulis dapatkan dari beberapa santri binaan penyalahguna Napza yaitu diantaranya ada yang sering mengalami jantung berdetak cepat, sering merasa pusing, sering merasa lemas, mudah marah, merasa sedih dan tertekan, mudah gelisah, mengalami gangguan tidur dan sulit beristirahat.

Stress pada dasarnya merupakan respon tubuh yang sifatnya non spesifik akibat adanya tuntutan beban. Misalnya bagaimana respon tubuh seseorang manakala yang bersangkutan mengalami beban pekerjaan yang berlebihan. Bila ia sanggup mengatasinya artinya tidak ada gangguan pada fungsi tubuh, maka dikatakan yang bersangkutan tidak mengalami stress. Tetapi sebaliknya bila ternyata ia mengalami gangguan pada satu atau lebih bagian tubuh sehingga yang bersangkutan tidak dapat menjalankan fungsi pekerjaannya dengan baik, maka ia disebut mengalami stress (Seyle, 1950 dalam Hawari,2001). isltilah stress berasal dari bahasa latin (strictus) yang bisa diartikan sebagai kesulitan, bahaya, dan penderitaan. Stress merupakan sindrom fihgt or flight, bila mana individu mengalami stress, 
maka individu tersebut akan merespon pemicu stress (stressor) dengan melakukan perlawanan (fight) atau menghindarinya (flight).

Hardjana (2002) meyebutkan stress merupakan kondisi yang tercipta apabila orang melihat ketidaksepadanan-entah nyata atau tidak nyata-, antara keadaan dan sistem sumber daya biologis, psikologis, dan sosial. Lazarus dan Folkman (dalam Sarafino, 2008) memandang stress bukanlah sekedar sebuah proses yang hanya meliputi pemicu stress (stressor) dan ketegangan saja; melainkan mereka menekankan juga pada pentingnya transaksi dan penyesuaian yang terusmenerus. Sarafino (2008) menegaskan bahwa stress bukanlah sekedar adanya stimulus atau respon, melainkan sebuah proses dari individu yang dapat memberikan pengaruh terhadap cara berperilaku, kognitif dan emosi.

Berdasarkan pendapat para ahli, maka stress merupakan keadaan saat individu merasakan tekanan karena adanya ancaman atau tuntutan yang dianggap melebihi kapasitasnya dan berpengaruh pada reaksi dan kondisi fisiknya. Pada kasus santri binaan yang menjalani rehabilitasi di Pondok Inabah, tuntutan saat menjalani proses rehabilitasi mungkin memberi tekanan yang melampaui batas kemampuan mereka. Untuk mengetahui ada tidaknya keadaan stress yang dialami santri binaan, digunakan indikator stress yang merupakan ukuran kuantitatif dan kualitatif yang sekaligus dapat menggambarkan tingkat stress individu. Indikator stress tersebut mengukur tiga aspek respon yaitu fisiologis, emosional, dan perilaku (Potter \& Perry, 2005).

Indikator fisiologis bersifat objektif dan lebih mudah diidentifikasi yaitu berupa kenaikan tekanan darah, tangan dan kaki dingin, postur tubuh yang tidak tegap, keletihan, sakit kepala, gangguan lambung, suara yang bernada tinggi, muntah, mual, diare, perubahan nafsu makan, perubahan berat badan, dan telapak tangan berkeringat. Indikator fisiologis ini secara umum dapat diamati. Indikator emosional dan perilaku sangat bersifat subjektif. Indikator emosional dan perilaku berupa kecamasan, depresi, kepenatan, kelelahan mental, perasaan tidak kuat, kehilangan harga diri, minat dan motivasi, ledakan emosi dan menangis. Kecenderungan membuat kesalahan, mudah lupa dan pikiran buntu, kehilangan perhatian terhadap hal-hal yang rinci, preokupasi, ketidakmampuan berkonsentrasi terhadap tugas, rentan terhadap kecelakaan, serta penurunan produktifitas dan kualitas kerja. Indikator emosional dan perilaku ini tidak mudah untuk diamati.

Sarafino (2008) membagi tiga jenis sumber stress yang dapat terjadi pada kehidupan individu, yaitu (i) sumber yang berasal dari individu. Ada dua bentuk stress yang berasal dari individu. Pertama adalah karena adanya penyakit. Penyakit yang diderita individu menyebabkan tekanan biologis dan psikologis sehingga menimbulkan stress. Sejauh mana tingkat stress yang dialami individu dengan penyakitnya dipengaruhi faktor usia dan keparahan penyakit yang dialaminya. Kedua adalah melalui konflik. Di dalam konflik individu memiliki dua kecenderungan yang berlawanan: menjauh dan mendekat. Individu harus memiliki dua atau lebih alternatif pilihan yang masing- masing memiliki kelebihan dan kekurangannya sendiri. Keadaan seperti ini banyak dijumpai saat individu dihadapkan pada keputusan- keputusan penting. (ii) Sumber yang berasal dari keluarga, Stress dalam keluarga dihasilkan melalui adanya perilaku, kebutuhan - kebutuhan dan kepribadian dari masing -masing anggota keluarga yang saling bertentangan sehingga berdampak kepada anggota keluarga lainnya. Konflik interpersonal ini dapat timbul dari masalah finansial, perilaku yang tidak sesuai, adanya tujuan yang berbeda antar anggota keluarga, bertambahnya anggota keluarga, perceraian, penyakit dan kecacatan yang dialami anggota keluarga dan kematian anggota keluarga. (iii) Sumber stress yang berasal dari komunitas dan masyarakat. Adanya hubungan manusia dengan lingkungan luar menyebabkan banyak kemungkinan munculnya sumber - sumber stress, misalnya stress yang dirasakan anak 
sekolah akibat adanya kompetisi akademik atau olah raga.

Setiap individu mempunyai persepsi dan respon yang berbeda-beda terhadap stress. Persepsi seseorang didasrkan pada keyakinan dan norma, pengalaman dan pola hidup, faktor lingkungan, struktur dan fungsi keluarga, tahap perkembangan keluarga, pengalaman masa lalu dengan stress serta mekanisme coping. Rasmun (2004), membagi stess menjadi tiga tingkatan yaitu stress ringan, stress sedang, dan stress berat. Stress ringan tidak sampai memunculkan gangguan fisiologis. Stress ringan umumnya dirasakan oleh setiap orang misalnya lupa, ketiduran, dikritik dan kemacetan. Stress ringan biasanya hanya terjadi beberapa menit atau beberapa jam. Situasi ini tidak akan menimbulkan penyakit kecuali jika dialami secara terus menerus. Stress tingkat sedang terjadi lebih lama dari beberapa jam hingga beberapa hari. Contoh stressor yang dapat menimbulkan stress sedang adalah kesepakatan yang belum selesai, beban kerja yang berlebihan, mengharapkan pekerjaan baru atau anggota keluarga yang pergi dalam waktu yang lama. Sedangkan stress berat adalah stress kronis yang dapat terjadi selama beberapa minggu hingga beberapa tahun. Contoh stressor yang dapat menimbulkan stress berat adalah hubungan suami istri yang tidak harmonis, kesulitan finansial, dan penyakit fisik yang lama.

\section{METODE}

Metode yang digunakan dalam penelitian ini adalah metode survey deskriptif dengan pendekatan kuantitatif. Data dikumpulkan dari responden menggunakan kuesioner. Tingkat stress diukur dengan menggunakan Depression Anxiety and Stress Scale 42 (DASS 42) dari Lovibond \& Lavibond (1995) yang sudah diadapatasikan kedalam bahasa Indonesia. Instrumen DASS 42 terdiri dari 42 pernyataan yang mengidentifikasi skala subyektif depresi, kecemasan, dan stress. Peneliti memodifikasi pernyataan tersebut dan menambahkan pernyataanpernyataan berdasarkan studi pustaka yang dilakukan oleh peneliti yang mencakup 3 subvariabel yaitu: fisik, emosi/psikologis, dan perilaku. Klarifikasi jawaban responden disusun berdasarkan perbedaan tingkat alternatif jawaban yang diberikan oleh responden.

Intrumen diberikan kepada 37 santri binaan/responden. Jumlah skor kriterium (bila setiap butir mendapat skor tertinggi) = $5 \times 42 \times 37=7770$. Untuk skor tertinggi setiap butir yaitu 5 . Jumlah butir instrumen ada 42 dan jumlah responden 37 . Untuk skor terendahnya digunakan $=1 \times 42 \times 37=1554$. Jika digambarkan dalam garis kontinum adalah sebagai berikut:

\section{Gambar 1 : Garis Kontinum Tingkat Stress}

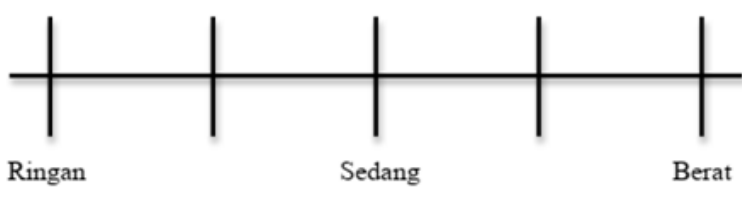

Keterangan Kelas: Ringan, Sedang, Berat

Uji validitas yang digunakan dalam penelitian ini adalah validitas muka (face validity). Face validity adalah teknik pengukuran alat ukur dengan cara mengkonsultasikan dengan ahlinya. Nazir (2014:149) menjelaskan, "face validity adalah penilaian para ahli terhadap suatu alat ukur". Face validity dilakukan dengan cara mengkonsultasikan kebenarannya kepada pembimbing yang berprofesi sebagai pekerja sosial.

Analisis data yang digunakan dalam penelitian ini adalah kuantitatif. Peneliti menggunakan program SPSS dalam pengolahan data. Proses analisis data kuantitatif ini meliputi pengeditan data, pengkuantifikasian data (penyusunan kategorisasi jawaban terhadap instrumen dan memberi skor atau kode), penyusunan lembar ringkasan data, dan menarik kesimpulan.

\section{HASIL DAN PEMBAHASAN}

\section{Karakteristik Responden}

Hasil penelitian diawali dengan karakteristik responden. Responden dalam penelitian ini adalah Korban Penyalahguna 
NAPZA yang mengikuti Rehabilitasi di Inabah Pondok Pesantren Suryalaya Tasikmalaya. Jumlah santri binaan yang dijadikan responden dalam penelitian ini yaitu 37 orang yang berusia 15 tahun sampai dengan 54 tahun. Responden yang mengikuti rehabilitasi di Inabah Pondok Pesantren Suryalaya ini $100 \%$ menganut agama islam. Karakteristik responden berdasarkan umur dapat dilihat pada tabel 4.2 sebagai berikut:

Tabel 1. Karakteristik Responden Berdasarkan Umur

\begin{tabular}{|l|c|c|r|}
\hline No. & Golongan Umur & Frekuensi & $\begin{array}{r}\text { Presentasi } \\
\%\end{array}$ \\
\hline 1. & $15-20$ Tahun & 16 & $43.24 \%$ \\
\hline 2. & $21-25$ Tahun & 7 & $18.92 \%$ \\
\hline 3. & $26-31$ Tahun & 4 & $10.82 \%$ \\
\hline 4. & $32-37$ Tahun & 5 & $13.52 \%$ \\
\hline 5. & $38-43$ Tahun & 3 & $8.10 \%$ \\
\hline 6. & $44-49$ Tahun & 1 & $2.70 \%$ \\
\hline 7. & $50-55$ Tahun & 1 & $2.70 \%$ \\
\hline \multicolumn{2}{|l|}{ Jumlah } & 37 & $100 \%$ \\
\hline
\end{tabular}

Sumber : Hasil Peneilitian Tingkat stress korban penyalahguna NAPZA dalam mengikuti rehabilitasi di inabah XV pondok pesantren suryalaya

Tabel 1 menggambarkan komposisi santri binaan berdasarkan usia. Terlihan bahwa berdasarkan umur santri binaan yang mengikuti rehabilitasi di Inabah Pondok Pesantren Suryalaya, umur $15-20$ tahun sebanyak 16 orang atau $43.24 \%$. Santri binaan dengan rentang usia ini adalah yang terbanyak yang menghuni dan mengikuti rehabilitasi di Inabah XV. Umur 15 - 20 tahun merupakan usia produktif atau usia pendidikan. Idelanya santri binaan ini sedang mengenyam pendidikan wajib di sekolah, akan tetapi mereka menjadi penyalahguna NAPZA dan harus mengikuti rehabilitasi di Inabah Pondok Pesantren Suryalaya. Karakteristik responden berdasarkan asal daerah dapat dilihat pada tabel di bawah ini :
Tabel 2. Karakteristik Responden Berdasarkan Asal Daerah

\begin{tabular}{|l|l|c|r|}
\hline No. & Asal Daerah & Frekuensi & Presentase \\
\hline 1. & Jawa Barat & 18 & $48.65 \%$ \\
\hline 2. & Jawa Tengah & 3 & $8.11 \%$ \\
\hline 3. & Jawa Timur & 1 & $2.70 \%$ \\
\hline 4. & DKI Jakarta & 2 & $5.41 \%$ \\
\hline 5. & NTB & 1 & $2.70 \%$ \\
\hline 6. & $\begin{array}{l}\text { Kalimantan } \\
\text { Selatan }\end{array}$ & 1 & $2.70 \%$ \\
\hline 7. & Sumatera Selatan & 3 & $8.11 \%$ \\
\hline 8. & Sumatera Utara & 4 & $10.81 \%$ \\
\hline 9. & NAD & 1 & $2.70 \%$ \\
\hline 10. & Kepulauan Riau & 2 & $5.41 \%$ \\
\hline 11. & Malaysia & 1 & $2.70 \%$ \\
\hline & \multicolumn{1}{|c}{ Jumlah } & 37 & $100 \%$ \\
\hline
\end{tabular}

Sumber : Hasil Peneilitian Tingkat stress korban penyalahguna NAPZA dalam mengikuti rehabilitasi di inabah $\mathrm{XV}$ pondok pesantren suryalaya

Tabel 2 menunjukkan santri binaan terbanyak berasal dari Provinsi Jawa Barat. Lokasi Inabah Pondok Pesantren Suryalaya yang berada di Provinsi Jawa Barat memudahkan aksesibilitas masyarakat Provinisi Jawa Barat untuk melakukan penjangkauan pelayanan rehabilitasi penyalahguna NAPZA. Karakteristik responden berdasarkan tingkat pendidikan dapat dilihat pada tabel 4.4 dibawah ini :

\section{Tabel 3. Karakteristik Responden} Berdasarkan Tingkat Pendidikan

\begin{tabular}{|l|c|c|r|}
\hline No. & Pendidikan & Frekuensi & Presentase \\
\hline 1. & SD & 4 & $10.81 \%$ \\
\hline 2. & SMP & 6 & $16.22 \%$ \\
\hline 3. & SMA & 19 & $51.35 \%$ \\
\hline 4. & D3 & 2 & $5.40 \%$ \\
\hline 5. & S1 & 5 & $13.51 \%$ \\
\hline 6. & S2 & 1 & $2.71 \%$ \\
\hline \multicolumn{2}{|c|}{ Jumlah } & 37 & $100 \%$ \\
\hline
\end{tabular}

Sumber : Hasil Peneilitian Tingkat stress korban penyalahguna NAPZA dalam mengikuti rehabilitasi di inabah XV pondok pesantren suryalaya

Tabel-tabel di atas menggambarkan karakteristik dari santri binaan yang mengikuti pelayanan rehabilitasi di Inabah Pondok Pesantren Suryalaya. Jumlah responden sebanyak 37 orang dengan rentang usia dari 15 - 54 Tahun, keseluruhan responden beragama islam, responden didominasi oleh usia 15-20 Tahun sebanyak 16 orang atau $43.24 \%$ dari keseluruhan santri binaan. 
Responden terbanyak berasal dari Provinsi Jawa Barat, hal ini disebabkan karena Inabah berlokasi di Kabupaten Tasikmalaya Provinsi Jawa Barat, yang membuatnya mudah diakses oleh masyarakat Jawa Barat sebagai tempat rehabilitasi. Tingkat pendidikan responden terbanyak adalah SMA yaitu sebanyak 19 orang atau $51.35 \%$.

\section{Tingkat Stress}

Penelitian ini dilakukan kepada 37 santri binaan yang mengikuti rehabilitasi di Inabah Pondok Pesantren Suryalaya. Jawaban yang diberikan responden terkait tingkat stress mereka pada tiga aspek yaitu aspek fisiologi, emosional, dan perilaku. Setelah diperoleh data pada ketiga aspek tersebut, peneliti menggabungkan hasil semua aspek dalam satu tabel untuk menggambarkan tingkat stress korban penyalahguna NAPZA dalam mengikuti rehabilitasi di Inabah Pondok Pesantren Suryalaya. Berikut adalah tabel rekapitulasi skor total dari seluruh aspek stress

Tabel 4. Rekapitulasi Skor Total Seluruh Aspek Stress

\begin{tabular}{|l|l|r|r|r|r|r|r|r|}
\hline \multirow{2}{*}{ No. } & \multirow{2}{*}{$\begin{array}{l}\text { Aspek } \\
\text { Stress }\end{array}$} & $\begin{array}{l}\text { Sangat } \\
\text { Sering }\end{array}$ & Sering & $\begin{array}{c}\text { Kadang- } \\
\text { Kadang }\end{array}$ & Pernah & $\begin{array}{c}\text { Tidak } \\
\text { Pernah }\end{array}$ & $\begin{array}{l}\text { Total } \\
\text { Skor }\end{array}$ & $\%$ \\
\hline 1. & $\begin{array}{l}\text { Aspek } \\
\text { Fisiologis }\end{array}$ & 55 & 64 & 219 & 220 & 234 & 792 & 21,38 \\
\hline 2. & $\begin{array}{l}\text { Aspek } \\
\text { Emosional }\end{array}$ & 285 & 320 & 483 & 356 & 227 & 1967 & 53,32 \\
\hline 3. & $\begin{array}{l}\text { Aspek } \\
\text { Perilaku }\end{array}$ & 120 & 164 & 312 & 204 & 136 & 936 & 25.30 \\
\hline \multicolumn{2}{|c|}{ Jumlah } & 460 & 548 & 1014 & 780 & 461 & 3704 & 100 \\
\hline
\end{tabular}

Sumber : Hasil Penelitian Tingkat stress korban penyalahguna NAPZA dalam mengikuti rehabilitasi di inabah XV pondok pesantren suryalaya

Berdasarkan tabel 4, total skor dari seluruh aspek adalah 3704 atau 100\%. Data di atas menunjukan bahwa skor tertinggi terdapat pada aspek emosional dengan perolehan skor sebanyak 1967 atau 53,32\%, dan skor terendah terdapat pada aspek fisiologis dengan perolehan skor sebanyak 792 atau $21,38 \%$. Sementara itu stress pada aspek perilaku masuk dalam kategori ringan dengan perolehan skor sebanyak 936, lebih tinggi dari aspek fisiologi. Hal tersebut menjelaskan bahwa respon stress pada aspek perilaku berada dalam interval kelas yang ringan. Meski tingkat stress dalam aspek perilaku masuk dalam kategori ringan, hal tersebut tetap menunjukan bahwa santri binaan mengalami stress dalam aspek perilaku, sama halnya dengan aspek fisologi yang tergolong dalam kategori ringan.

Untuk mengetahui tingkat stress pada seluruh aspek, peneliti menggunakan cara sebagai berikut :

$$
\begin{array}{ll}
\text { Skor Tertinggi } & \text { Nilai Tes Tertinggi } \times \text { Jumlah Soal } \\
& \times \text { Jumlah Responden } \\
= & 5 \times 42 \times 37 \\
= & 7770 \\
= & \text { Nilai Tes Terendah } \times \text { Jumlah Soal } \\
& \quad \times \text { Jumlah Responden } \\
= & 1 \times 42 \times 37 \\
\text { Skor Terendah } \quad & 1554 \\
= & (\text { ringan, sedang, berat }) \\
\text { Banyaknya Kelas }= & (\text { skor tertinggi }- \text { skor terendah }) \\
\text { Interval } & : \text { Banyak Kelas } \\
= & (7770-1554): 3 \\
= & 2072
\end{array}
$$

Secara kontinum, gambaran tingkat stress pada ketiga aspek dari korban penyalahguna NAPZA dalam mengikuti rehabilitasi di Inabah Pondok Pesantren Suryalaya dapat digambarkan sebagai berikut

\section{Gambar 2 Garis Kontinum Tingkat Stress}

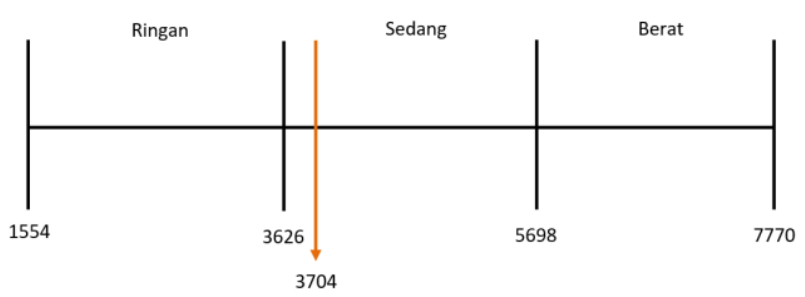

Keterangan :

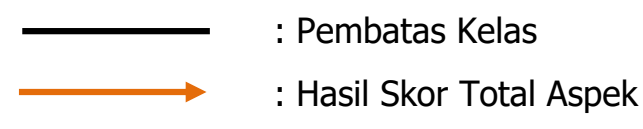

Ada tiga tingkatan stress menurut Rasmun (2004), yaitu ringan, sedang dan berat. Gambar 2 diatas menunjukkan bahwa total skor dari keseluruhan aspek stress yang 
dialami santri binaan dalam mengikuti rehabilitasi di Inabah Pondok Pesantren Suryalaya berada dalam kategori sedang. Tingkatan stress tersebut ditunjukan dari gejala-gejala yang dialami pada ketiga aspek stress. Apabila keadaan ini dibiarkan tanpa ada upaya untuk mengurangi tingkat stress para santri binaan, dikhawatirkan tingkatan stress tersebut akan meningkat sehingga berdampak pada tidak efektiknya proses rehabilitasi yang diterima.

\section{Penyebab Stress Santri Binaan}

Peneliti melakukan analisa masalah pada faktor penyebab terjadinya stress yang dialami oleh santri binaan dalam mengikuti proses rehabilitasi di Inabah Pondok Pesantren Suryalaya. Menurut Weiten (2002) terdapat beberapa kejadian yang dapat menyebabkan stress pada individu yaitu: frustasi, konflik, perubahan dan tekanan. Frustasi terjadi pada situasi di mana suatu tujuan terhalangi. Secara objektif peniliti menemukan sebagian besar dari santri binaan mengalami frustasi. Peraturan yang membatasi santri binaan dalam menghubungi orang tuanya, untuk beraktivitas dan bersosialisasi, menyebabkan tujuan-tujuan atau keinginan dari santri binaan terhambat. Menonton televisi atau hal-hal lain yang biasanya dilakukan orang pada umumnya dibatasi atau dihalangi oleh peraturan yang ada di Inabah Pondok Pesantren Suryalaya.

Di sisi lain, para santri binaan yang memiliki masalah penyalahgunaan Napza beserta masalah turunannya, sudah tentu tidak memiliki kemampuan pengelolaan diri atau coping strategy yang memadai untuk mengatasi berbagai tekanan yang mereka alami. Beberapa upaya yang dilakukan santri binaan dalam "mengatasi" tekanan atau stress yang dialmai diantaranya merokok, tidur, atau berdiam diri.

Faktor kedua penyebab stress adalah konflik. Konflik terjadi ketika dua atau lebih keinginan berkompetisi untuk dimunculkan atau kondisi dimana kita harus menentukan pilihan. Terdapat tiga tipe konflik (Weiten, 2002) yaitu, yang pertama saat dihadapkan pada pilihan yang harus dibuat diantara dua tujuan yang menyenangkan. Diantara tiga macam konflik, tipe ini paling rendah tingkat stressnya. Kedua adalah saat dihadapkan pada pilihan yang harus dibuat diantara dua tujuan yang tidak menyenangkan. Tipe konflik ini merupakan yang paling tidak menyenangkan dan paling tinggi tingkat stressnya. Ketiga adalah saat individu dihadapkan pada dua pilihan di mana yang satu menyenangkan sedangkan yang lainnya tidak menyenangkan. Konflik ini merupakan konflik umum dan tingkat stressnya cukup. Santri binaan sering mengalami konflik dalam memilih sebuah pilihan baik itu yang menyenangkan ataupun yang tidak menyenangkan. Bahkan dalam memilih sebuah pilihan santri binaan harus mengikuti aturan yang sudah diatur oleh Inabah Pondok Pesantren Suryalaya. Otoritas dari Inabah dalam mengatur aktifitas santri binaan berpengaruh terhadap terjadinya stress dari santri binaan.

Faktor ketiga penyebab stress dari seorang individu adalah perubahan (Weiten, 2002). Perubahan hidup adalah pergantian apa saja yang nyata dalam kehidupan seseorang yang membutuhkan penyesuaian diri kembali. Santri binaan yang mengikuti rehabilitasi di Inabah dipaksa untuk mampu menyesuaikan diri dengan lingkungan yang berbeda dan aktifitas yang berbeda dari apa yang sebelumnya biasa mereka lakukan. Keadaan tersebut menyebabkan terjadinya stress pada mereka.

Faktor keempat penyebab stress adalah tekanan (Weiten, 2002). Tekanan meliputi pengharapan atau tuntutan kepada seseorang untuk berperilaku tertentu yang tidak sesuai dengan keyakinannya sendiri atau diluar kemampuannya. Ada dua sumber tekanan yaitu, yang pertama yang muncul dari dalam, yaitu tuntutan dalam diri individu sendiri yang terlalu tinggi namun tidak ada kemampuan untuk mencapainya meskipun telah berusaha keras. Contoh tuntutan dari dalam diri santri binaan yang menyebabkan santri binaan mengalami stress adalah ingin keluar dari Inabah, akan tetapi kemampuan 
dan usaha keras yang sudah dilakukan belum mampu membuatnya bisa keluar dari Inabah. Keberhasilan rehabilitasi ditentukan oleh penilaian dari keluarga santri binaan atau instansi yang merujuk santri binaan dan penilaian pihak inabah sendiri.

Sumber tekanan yang kedua datangnya dari luar- Kondisi tekanan dari luar yang terjadi di Inabah Pondok Pesantren Suryalaya adalah peraturan yang membatasi aktifitas santri binaan dan dari otoritas lainnya yang dilakukan Inabah kepada santri binaan dalam rangka proses rehabilitasi. Hal tersebut menjadi salah satu penyebab terjadinya stress yang dialami santri binaan.

Melihat masalah yang dialami oleh para santri binaan, maka secara keseluruhan ketiga aspek stress saling berhubungan satu sama lain. Keadaan emosional akan mempengaruhi kondisi fisiologis, begitu juga dampak fisiologis dan emosional akan mempengaruhi perilaku. Saling mempengaruhi antar aspek tersebut hanya dirasakan oleh setiap individu, yang apabila tidak segera ditangani akan munculkan perilaku-perilaku maladaftif yang merugikan dan membuat responden tidak berfungsi secara sosial.

Kondisi stress dapat memicu timbulnya masalah kesehatan dan psikologis pada individu. Pelayanan rehabilitasi yang diberikan lembaga dapat menjadi bekal yang baik dan bisa dimanfaatkan korban penyalahguna NAPZA jika dilakukan dengan benar dan sungguh-sungguh. Akan tetapi apabila dalam pemberian pelayanannya mengakibatkan santri binaan mengalami stress negatif, maka dibutukan pemecahan masalah yang berkaitan dengan hal tersebut. Penting untuk mengkaji proses rehabilitasi korban penyalahguna NAPZA yang memadai dan tepat, karena kualitas dari proses rehabilitasi akan sangat menentukan sejauh mana keberhasilan intervensi dalam mengembalikan keberfungsian sosial korban penyalahguna NAPZA.

\section{Sistem Sumber Yang Bisa Dimanfaatkan}

Sistem sumber merupakan kekuatan potensial yang dapat membantu sistem kegiatan atau klien dalam menyelesaikan isu atau permasalahan yang sedang dihadapi. Terdapat tiga klasifikasi sistem sumber menurut Allen Pincus dan Anne Minahan dalam Dwi Heru Sukoco (2011) yang dapat dimanfaatkan. Sistem sumber tersebut adalah:

(i) Sistem Sumber Informal. Sistem sumber informal atau alamiah dapat berupa keluarga, teman, tetangga maupun orang lain yang bersedia membantu. Bantuan yang dapat digali dan dimanfaat dari sumber alamiah oleh santri bina adalah, kasih sayang, dukungan emosional, informasi, nasehat, visi, dan pelayanan-pelayanan kongkrit lainnya. Dukungan sosial tersebut dapat menjadi motivasi diri untuk mencapai kehidupan yang lebih baik bagi santri binaan. Sistem sumber informal ini leibh banyak dapat diperoleh dari teman sesama santri binaan yang mengikuti rehabilitasi di Inabah Pondok Pesantren Suryalaya, termasuk dari para pembina yang siap sedia selama 24 jam untuk membimbing.

(ii) Sistem Sumber Formal. Sistem sumber formal adalah sumber yang dapat memberikan bantuan atau pelayanan langsung kepada para anggotanya. Sistem formal ini berada di dalam suatu organisasi atau asosiasi formal yang memiliki tujuan untuk meningkatkan minat anggota. Sistem sumber tersebut juga dapat membantu anggotanya untuk bernegosiasi dan memanfaatkan sistem sumber kemasyarakatan. Sistem sumber formal yang dapat dimanfaatkan oleh santri binaan adalah Yayasan Inabah Pondok Pesantren Suryalaya, pekerja sosial yang berkerja di Inabah Pondok Pesantren Suryalaya, pembinaan yang memberikan bimbingan di Inabah Pondok Pesantren Suryalaya, dan Psikolog atau pekerja sosial yang dapat memberikan terapi manajemen stress untuk santri binaan yang mengikuti rehabilitasi dan juga untuk memodifikasi atau memperbaiki strategi dan metode pembinaan dalam proses rehabilitasi.

(iii) Sistem Sumber Kemasyarakatan. Sistem sumber kemasyarakatan adalah sumber yang dapat memberikan bantuan 
kepada masyarakat secara umum. Sumber yang dimaksud dapat berupa lembaga atau dinas pemerintahan yang ada. Dalam kaitannya dengan kebutuhan peningkatan kualitas pelayanan rehabilitasi penyalahguna NAPZA di Inabah Pondok Pesantren Suryalaya, sistem sumber yang dapat diakses adalah Dinas Sosial Kabupaten Tasikmalaya. Sistem sumber yang dapat diperoleh adalah segala bentuk program dan kebijakan kesejahteraan sosial yang terkait dengan rehabilitasi penyalahguna NAPZA baik yang ditujukan bagi para santri binaan maupun bagi lembaga penyelenggara dalam hal ini Inabah Pondok Pesantren Suryalaya.

\section{SIMPULAN DAN SARAN}

Penelitian ini dilakukan dengan latarbelakang adanya data mengenai kasus stress yang dialami santri binaan di Inabah Pondok Pesantren Suryalaya. Penelitian dilakukan kepada 37 orang santri binaan yang mengikuti program rehabilitasi secara penuh di dalam Pondok Inabah Pesantren Suryalaya. Pengukuran tingkat stress dilakukan dengan menyebarkan angket pernyataan yang dibagi kedalam tiga bagian aspek dalam stress yaitu aspek fisiologis, aspek emosional, dan aspek perilaku. Hasil dari pengukuran tingkat stress korban penyalahguna NAPZA dalam mengikuti rehabilitasi di Inabah Pondok Pesantren Suryalaya menunjukkan bahwa tingkat stress dalam aspek fisiologis memiliki skor 792 atau sebesar $21,38 \%$ berada dalam kategori rendah.

Tingkat stress pada aspek emosional memiliki skor sebanyak 1967 atau sebesar $53,32 \%$, ini menunjukan aspek emosional berada dalam tingkat sedang. Tingkat stress pada aspek perilaku memiliki skor sebanyak 936 atau sebesar 25,30\%. Hal ini menunjukkan bahwa aspek perilaku dalam tingkat stress berada dalam kategori ringan. Hasil skor dari keseluruhan aspek stress yang diukur menunjukkan skor tertinggi terdapat pada aspek emosional dan skor terendah terdapat pada aspek fisiologis. Oleh karena itu diperlukan tindakan penanganan kepada para santri binaan dan modifikasi pendekatan atau strategi proses rehabilitasi untuk menangani dan mencegah kejadian stress tersebut.

Saran dari penulis secara operasional mengarah pada pemanfaatn sistem sumber yang tersedia, sistem sumber tersebut seperti keluarga atau teman sebagai sistem sumber informal, lalu kemudian sistem sumber formal beruapa bentuk pelayanan yang diberikan oleh inabah kepada anak binaan. Selama proses rehabilitasi berlangsung santri binaan hanya bisa memperoleh penanganan stres ini melalui sistem sumber formal. Maka dari itu, peningkatan kapasitas penangan stress untuk sumber daya manusia atau pemberi pelayanan rehabilitasi dari inabah perlu ditingkatkan agar mampu memnekan angkat stres yang terjadi di Inabah Pondok Pesantren Suryalaya.

\section{DAFTAR PUSTAKA}

Adi Fahrudin. 2012. Pengantar IImu Kesejahteraan Sosial. Bandung : PT. Refika Aditama

Dwi Heru Sukoco. 1991. Profesi Pekerjaan Sosial dan Proses Pertolongannya, Bandung: Koperasi Mahasiswa Sekolah Tinggi Kesejahteraan Sosial.

Garvin. 2011. Group Work. Bandung: STKS Press.

Greesberg, J. S. 2002. Comprehensive Stress Management. (2nd.). Newyork: McGraw Hill.

Hardjana, A. M. 2002. Stress tanpa distress: Seni mengelola Stress. (7th ed.) Yogyakarta: Kanisius.

Hawari, Dadang. 2001. Manajemen Stress, Cemas dan Depresi. Jakarta : Balai Penerbit FKUI

Juda Damanik. 2008. Pekerjaan Sosial Jilid I. Jakarta: Direktorat Pembinaan Sekolah Menengah Kejuruan, Drektorat Jendral Manajemen Pendidikan Dasar dan Menengah, Departemen Pendidikan Nasional.

Johnson, Jerry L. (2004). Fundamental of Subtance Abuce Practice. Australia, Canada, Mexico, Singapore, Spain, 


\begin{tabular}{|c|c|c|c|c|}
\hline Share: Social Work Jurnal & VOLUME: 10 & NOMOR: 1 & HALAMAN: $29-39$ & $\begin{array}{c}\text { ISSN: 2339-0042 (p) } \\
\text { ISSN: 2528-1577 (e) } \\
\text { DOI: 10.24198/share.v10i1.25992 }\end{array}$ \\
\hline
\end{tabular}

United Kingdom, United Stated: Thomson Brools/cole.

Marbun, Jumayar. (2017) Pekerja Sosial dengan NAPZA/Narkoba. Bandung: STKS PRESS

Moh. Nazir. 2014. Metode Penelitian. Bogor: Ghalia Indonesia.

Parasian Simanungkalit. 2011，Globalisasi Peredaran Narkoba dan Penanggulangannya di Indonesia. Jakarta Selatan: Yayasan Wajar Hidup

Potter \& Perry. 2005. Fundamental Of Nursing : Concept, Process \& practice. (Renata Komalasari. Et. All, Penerjemah) Jakarta: EGC 2005

Rasmun. 2004. Stress, koping dan Adaptasi Teori dan Pohon Masalah Keperawatan. Jakarta : CV Sagung Seto

Romas, j. A., \& Sharma, M. 2000. A Comprenhennsive Workbook For Managing Change \& promoting Helt. (2 nd.). Massachusett: Allyn \& bacon.

Sarafino, E. P. 2008. Helth psycology: Biopschosicial Interaction (6th ed.). New York: John Wiley \& Sons

Skidmore, Rex A. 1991. Introduction to Social Work. Fifth Edition. Prentice-Hall International Inc.

Smeltzer. S. C \& Bare. B. G. 2008. Brunner \& Sudarth's textbook of Medical Surgical Nursing. Volume 1.(11 ${ }^{\text {th }}$ ed). Philladelpia: Lippicont

Sugiyono. 2011. Metode penelitian kuatitatif, kualitatif dan $R \& D$. Bandung: Alfabeta

Sugiyono. 2015. Penelitian Pendidikan: Pendekatan Kuantitatif, Kualitatif dan $R \& D$. Bandung: Alfabeta.

Weiten, W. 2007. Psychology: themes \& variations. (7th ed). United states of America: Thomson Wadsworth

Yusuf, S. 2004. Mental Hydiene: Pengembangan kesehatan Mental dalam Kajian Psikologi dan agama. Bandung; Pustaka Bani Qurasy.

\section{Sumber Lain}

Undang-Undang Nomor 5 Tahun 1997 tentang Psikotropika.

Undang-Undang Nomor. 35 Tahun 2009 Mengenai Narkotka.

http://regional.kompas.com/read/2010/03/05 20274591/Sudah.7.Santri.Inabah.Di temukan.Tewas (diakses pada pukul 09.00, Selasa, 08 Agustus 2010)

http://repository.usu.ac.id/bitstream/1234567 89/38090/4/Chapter\%20II.pdf (Diakses pada Rabu 09 Agustus 2017 pukul 16.00)

Start An Addiction Social Work Career. 2013. http://careersinpsychology.or/psych ology-careers/. (diakses pukul 16:58, Rabu, 09 Agustus 2017). 